\title{
Problematika Pembelajaran Daring Mata Pelajaran PAI di Masa Covid-19
}

\author{
Fitriyana ${ }^{1}$, Firda Ayu Wahyuni ${ }^{2}$ \\ Institut Dirosat Islamiyah Al-Amien Prenduan Sumenep \\ 1anafitriyana@gmail.com, ${ }^{2}$ Firdabakri@gmail.com
}

\begin{abstract}
Abstrak
Tujuan artikel ini yaitu untuk mengetahui problematika peserta didik dan upaya orang tua peserta didik dalam mengatasi problematika yang terjadi pada peserta didik dalam proses pembelajaran secara daring atau PJJ. Penelitian ini menggunakan metode penelitian kualitatif Lapangan yang mana seorang peneliti secara langsung terjun ke lapangan mengamati dan tehnik pengumpulan data yang digunakan yaitu dengan observasi dan wawancara kepada peserta didik dan orang tua peserta didik guna untuk mengetahui problematika pembelajaran daring yang dialami peserta didik. Dalam situasi pandemi yang mengharuskan pembelajaran daring bagi peserta didik tentu mengalami problematika seperti yang terjadi di SDN Totosan Kec Batang-batang. Adapun problematika yang sering dihadapi yaitu pembelajaran kurang maksimal dan kondusif, kurangnya pemahaman materi PAI oleh peserta didik dan orang tua peserta didik, kurangnya ketersediaan handphone dan koneksi jaringan yang buruk serta sibuknya orang tua peserta didik dalam mendampingi peserta didik ketika pembelajaran daring dimulai. Sehingga orang tua peserta didik perlu upaya untuk mengatasi problematika yang terjadi seperti terus memberi dukungan dan bimbingan sebisa mungkin pada peserta didik serta mengadakan belajar kelompok sesama peserta didik yang dibimbing langsung oleh orang tua peserta didik yang lebih paham.
\end{abstract}

Kata Kunci: covid-19, problematika pembelajaran, pendidikan agama Islam 


\begin{abstract}
The purpose of this article is to determine the problem of students and the efforts of parent od students in overcroming problems that occur in students in the learning procces online or PJJ. This research uses qualitative field research methods in which a researcer goes directly to the field observing and data collection techniques used, namely by observation and interviews with students and parent of students in order to find out the problems of online learning experinced by students. In a pandemic situation that requires online learning for students, of course, they experience problems such as what happened in Totosan, Batang Batang District. As for the problems that are often faced, namely learning is less than optimal and confusive, lac of understanding of PAI material by student and parents of students, lack of cellphone availability and poor network connection and busy parents of students when online learning begins. So that of students need efforts to evercome the problems that occur, such as continuing to provide support and guedance as much as possible to students as well as holding peer group learning guided directly by parentsof student who understand better.
\end{abstract}

Keywords: covid-19, Islamic religion education, learning problems

\title{
PENDAHULUAN
}

Di pertengahan tahun 2020, dunia digemparkan dengan mewabahnya virus baru yaitu covid_19, Sehingga untuk sementara lembaga pendidikan ditutup guna sebagai upaya menahan penyebaran pandemi covid-19 diseluruh dunia yang mana berdampak pada jutaan pelajar. ${ }^{1}$ Kebijakan belajar learn from home pada lembaga pendidikan dengan sistem daring atau belajar dari rumah sangat tidak kondusif dan proses pembelajaran dari rumah melalui pjj idealnya tetap dapat

\footnotetext{
1 Yuliana, "Corona Virus Diseases (Covid-19): Sebuah Tinjauan Literatur" 2 (2020).
} 
memenuhi kebutuhan siswa untuk mengembangkan jenjang pendidikannya. $^{2}$

Covid-19 bukanlah alasan untuk memberhentikan proses belajar mengajar karena pendidikan sangat penting dan tidak bisa lepas dari kehidupan manusia, pendidikan agama Islam pada dasarnya adalah salah satu cara yang dilakukan dengan tujuan menjadikan pribadi yang berkualitas dalam Islam. ${ }^{3}$ Dan Undangundang RI Nomor 20 Tahun 2003 tentang Sistem Pendidikan Nasional Bab 1 Pasal 1 (1) pendidikan yang diartikan sebagai sebuah usaha untuk mewujudkan suasana belajar dan proses belajar agar peserta didik secara aktif mengembangkan potensi dirinya untuk memiliki kekuatan spiritual keagamaan, pengendalian diri, kepribadian, kecerdasan, akhlak mulia, dan keterampilan yang diperlukan dirinya, serta masyarakat, bangsa dan negara. ${ }^{4}$

Dilaksanakannya Belajar dari Rumah dengan sistem Pembelajaran Jarak Jauh (PJJ) atau dengan sistem daring yang menggunakan internet. Undang-undang No. 20 tahun 2003 pasal 1 ayat 15, yaitu PJJ merupakan proses belajar mengajar yang pesertadidiknya terpisah dengan gurunya dan pembelajarannya menggunakan berbagai sumber belajar melalui teknologi komunikasi, informasi seperti: whatsapp, telegram, zoom meeting, google meet, google classroom, ruang guru dan aplikasi lainnya, dalam pelaksanaan PJJ yaitu pembelajaran jarak jauh

\footnotetext{
${ }^{2}$ Fieka Nurul Arifa, "Tantangan Pelaksanaan Kebijakan Belajar dari Rumah dalam Masa Darurat Covid-19” XII (2020): 14.

${ }^{3}$ Suci Febrientika Rahman, "Problematika Pembelajaran Agama Islam pada Masa Pandemi Covid-19 Di SMP Islam Nurus Salam" 3 (2020).

${ }^{4}$ Susiana, "Problematika Pembelajaran PAI di SMKN 1 Turen," At Tariqah 2 (2017): 73.
} 
dalam jaringan (daring) sesuai dengan ketersediaan sarana yang ada di rumah. ${ }^{5}$

Melihat kenyataan yang terjadi di lingkungan masyarakat saat ini, sebagian orang tua peserta didik yang jarang punya handphone (android) atau komputer untuk mengikuti proses pembelajaran daring, termasuk peserta didik sendiri. Kondisi seperti ini yang menjadi problem bagi peserta didik untuk mengikuti proses pembelajaran jarak jauh akibat ketiadaan fasilitas di rumah untuk mengikuti PJJ, sementara pelayanan pendidikan bagi peserta didik harus dipenuhi. Sebagaimana dijelaskan dalam UUD 1945 pasal 31 ayat (1) menyatakan bahwa setiap warga berhak mendapat pendidikan. Sedangkan Permasalahan yang terjadi di Desa Totosan Dsn Ares Laok Kecamatan Batang-batang bukan hanya pada ketersediaan fasilitas pembelajaran saja, namun kuota (pulsa) yang disambungkan ke internet membutuhkan biaya cukup tinggi, yang mana untuk memfasilitasi kebutuhan pembelajaran daring, terutama orangtua peserta didik kebanyakan dari kalangan ekonomi menengah ke bawah, tidak memiliki anggaran dalam menyediakan jaringan internet, meskipun jaringan internet sudah terpenuhi, peserta didik menghadapi kesulitan akses jaringan internet karena faktor tempat tinggal di daerah pedesaan, terpencil. Walaupun ada tower terkadang jaringan yang tidak stabil. Hal ini juga yang menjadi permasalahan

\footnotetext{
5 Asmuni, "Problematika Pembelajaran Daring di Masa Pandemi Covid-19 dan Solusi Pemecahannya," Penelitian dan pengembangan 7 (2020): 281.
} 
banyak terjadi pada peserta didik yang mengikuti pembelajaran daring, sehingga pelaksanaannya kurang efektif. ${ }^{6}$

Beberapa penelitian tentang problematika pembelajaran PAI pada masa pandemi telah dilakukan sebelumnya di antaranya penelitian yang dilakukan M. Yusuf Amin Nugroho yang berjudul Metode, Media dan Problematika Pembelajaran PAI Berbasis Daring di Tingkat Madrasah Aliyah. Dalam penelitiaanya mengenai problematika yang dihadapi adalah di antaranya akses internet yang terbatas, penggunaan media yang kurang terkenal, kegiatan belajar mengajar yang pasif dan sistem evaluasi yang kurang efektif. ${ }^{7}$

Selanjutnya penelitian yang dilakukan oleh Mulia Guswanti dan Rengga Satria, dengan judul Problematika Pembelajaran Dalam Jaringan (Daring) pada Mata Pelajaran Pendidikan Agama Islan di SMA Negeri 4 Pariaman. Penelitian ini menghasilkan bahwa problematika yang dihadapi dalam pembelajaran daring yaitu pendidik yang kurang menguasai tekhnologi, peserta didik yang tidak termotivasi dalam belajar, sarana dan prasana yang kurang memadai dan pembelajaran daring yang tidak efektif. Sedangkan upaya yang dilakukan adalah mengadakan bimbingan teknis bagi pendidik yang tidak menguasai tekhnologi, pendidik memotivasi dan melaksanakan bimbingan belajar, tersedianya sarana prasarana seperti paket internet dan lab komputer bagi

\footnotetext{
6 Keputusan Bersama Menteri Pendidikan dan Kebudayaan, Menteri Agama, Menteri Kesehatan dan Menteri Dalam Negeri No. 01/KB/2021, No. 516 Tahun 2020, No. HK.03.01/Menkes/363/2020, dan No. 440-882 tentang Panduan Penyelenggaraan Pembelajaran pada Tahun Ajaran 2020/2021 dan Tahun Akademik 2020/2021 di masa Covid-19

${ }^{7}$ M. Yusuf Amin Nugroho, "Metode, Media, dan Problematika Pembelajaran PAI Berbasis Daring di Tingkat Madrasah Aliyah," Paramurobi: Jurnal Pendidikan Agama Islam 3, no. 2 (2020): 1-14.
} 
peserta didik yang tidak memiliki hp android dan pengoptimalan pembelajaran yang dilakukan oleh pendidik. 8

Sedangkan penelitian ini bertujuan untuk menganalisis problematika yang dihadapi peserta didik dalam pembelajaran PAI pada saat covid-19 dan upaya yang dilakukan oleh orang tua dalam mengatasi problematika tersebut di desa Totosan dusun Ares Laok kecamatan Batang-batang.

\section{METODE PENELITIAN}

Penelitian ini menggunakan pendekatan kualitatif lapangan, studi kasus di Desa Totosan Batang-batang Sumenep. ${ }^{9}$ Proses pengumpulan data dilakukan dengan: wawancara, 10 observasi, ${ }^{11}$ dan dokumentasi. ${ }^{12}$ Data yang dikumpulkan hal-hal yang berkenaan dengan problematika selama pembelajaran daring yang dirasakan oleh peserta didik dan orang tua. Adapun tahapan yang ditempuh ada tiga tahapan, yaitu: pertama tahap pra lapangan; yaitu terdiri dari menyusun rancangan penelitian, memilih lapangan penelitian, mengurus penelitian, menjajaki dan menilai keadaan lapangan, memiliki dan memanfaatkan informan, menyiapkan perlengkapan penelitian, mengantisipasi persoalan etika penelitian. Tahap kedua yaitu tahap Pekerjaan

\footnotetext{
8 Mulia Guswanti and Rengga Satria, "Problematika Pembelajaran Dalam Problematika Pembelajaran Dalam Jaringan (Daring) Pada Mata Pelajaran Pendidikan Agama Islam Di SMA Negeri 4 Pariaman," An-Nuha 1, no. 2 (2021): 116-124.

9 Lexy J. Moleong, Metodologi Penelitian Kualitatif (Bandung: PT. Remaja Rosdakarya, 2011), 155.

${ }^{10}$ Mohammad Nazir, Metode Penelitian (Jakarta: Galia Indonesia, 2006), 193-194.

${ }^{11}$ Sumadi Suryabrata, Metodelogi Penelitian Kualitatif (Jakarta: Rajawali Perss, 1991), 94.

${ }^{12}$ Cholid Narbuko dan Abu Ahmadi, Metodologi Penelitian (Jakarta: Bumi Aksara, 2001), 70 .
} 
Lapangan; yang terdiri dari memahami penelitian dan persiapan diri, memasuki lapangan, berperan serta sambil mengumpulkan data.

Sedangkan yang terakhir yaitu tahap Analisis Data; meliputi kegiatan organisasi dan kategorisasi data, menemukan tema dan merumuskan hipotesis, serta menganalisis atau mendeskripsikan data berdasarkan hipotesis.

\section{HASIL DAN PEMBAHASAN}

Problematika Peserta Didik dalam Pembelajaran PAI pada Saat Covid-19 Desa Totosan Dusun Ares Laok Kecamatana Batangbatang

Ada beberapa problem atau masalah yang didapati dalam kegiatan pembelajaran antara lain keterbatasan sumber belajar, alokasi waktu, dan keterbatasan dana yang tersedia. Dalam problematika yang sedang terjadi saat ini pendidikan tetap memiliki peran yang sangat penting bagi peserta didik saat menghadapi pandemi Covid-19 ini. Karena pada dasarnya pembelajaran pendidikan agama Islam adalah salah satu cara yang dilakukan dengan tujuan pengembangan kepribadian yang berjalan selamanya, baik formal atau nonformal, tujuannya untuk menjadikan pribadi yang lebih berkualitas. Menurut Rahman ${ }^{13}$ bahwa terdapat beberapa problematika pembelajaran pendidikan agama Islam yang dihadapi oleh peserta didik pada masa pandemi Covid-19 seperti kurangnya melakukan budaya

\footnotetext{
13 Rahman Suci Febriyantika, Problematika Pembelajaran Pendidikan Agama Islam (PAI) pada Masa Pandemi Covid-19 di Smp Islam Nurussalam Al-Khoir Mojolaban Sukoharjo Tahun Pelajaran 2019/2020, n.d.
} 
literasi, tingkat pemahaman agama yang berbeda-beda, kemauan siswa yang rendah untuk belajar, keberagaman pengetahuan siswa yang berbeda-beda, lingkungan keluarga, lingkungan masyarakat dan lingkuangan bermain.

Problematika yang dihadapi peserta didik Sekolah Dasar dalam Pembelajaran Daring Mata Pelajaran PAI pada saat Covid19 di Desa Totosan Dusun Ares Laok kecamatan Batang-batang adalah pembelajaran daring sangat tidak kondusif karena anakanak dan orang tua susah untuk memahami materi yang disampaikan guru dan juga belum mampu membangun interaksi dengan siswa sehingga hasil yang diharapkan dari pembelajaran daring itu tidak maksimal. Selain hal itu, peserta didik kurang aktif dan tertarik dalam mengikuti pembelajaran daring meskipun didukung dengan fasilitas yang memadai dari segi ketersediaan perangkat handphone/ gadget, dan jaringan internet. Kurangnya kepedulian akan pentingnya literasi dan pengumpulan tugas portofolio, sering menghambat jalannya belajar daring.

Problematika lain yang dialami peserta didik di SDN Totosan II Kecamatan Batang-batang mengenai pembelajaran daring yaitu kurangnya dukungan dari pihak sekolah seperti pengawasan dari para guru, yang mana guru atau wali kelas tersebut hanya mengirim tugas saja tanpa membimbing peserta didik sampai benar-benar proses pembelajaran daring itu selesai sehingga tugas yang seharusnya dikumpulkan dalam tenggang waktu satu minggu sering molor menjadi dua minggu. Kurangnya pengawasan dalam pembelajaran akan membuat peserta didik 
menjadi kurang minat dalam belajar agama. Peserta didik yang tidak bersungguh-sungguh dalam mempelajari agama pasti tujuannya hanya ingin mencari nilai saja, bukan untuk membekali dirinya dengan pengetahuan agama sebagai sarana untuk melaksanakan ibadah kepada Allah SWT.

Hal tersebut tidak hanya berdampak pada peserta didik saja melainkan juga berdampak pada orang tua dalam pengeluaran biaya untuk membeli paket internet, serta bantuan kuota gratis dari pihak sekolah juga tidak ada, lebih-lebih jika proses pembelajaran berlangsung seringkali koneksi internet terganggu. Bagi peserta didik yang tidak memiliki perangkat handphone/ gadget, misalnya Irfan, yang digunakan sebagai media belajar daring akan susah mendapatkan pelajaran, kalaupun ada, itu milik orangtua. Jika belajar daring, mereka harus bergantian menggunakannya dengan orangtua, dan mendapat giliran setelah orangtua pulang kerja yang tidak menentu, yang terkadang pulang pada siang hari, sore hari, bahkan malam hari. Sementara itu umumnya jadwal pembelajaran daring di sekolah dilakukan mulai pagi hari hingga siang hari. Problematika ini juga dialami oleh Alfian selaku siswa di SDN TOTOSAN I kelas II Kecamatan Batang-batang, kesibukan orang tua dalam mendampingi anaknya dalam proses pembelajaran daring tentu menjadi kendala baginya, karna jika peserta didik tidak dipantau maka pelajaran yang disampaikan menjadi kurang maksimal dan peserta didik kurang memahami.

Dalam hal ini peran orang tua sangat penting karena orang tua adalah tempat Madrasat al-Ula untuk anak, di 
lingkungan keluarga inilah anak akan mendapatkan banyak pendidikan agama dan bimbingan tentang keagamaan, karena sebagian besar aktivitas anak berada di lingkungan keluarga. Dengan demikian, jika keluarga peserta didik tersebut tingkat keagamaannya baik dan selalu memberikan support kepada anaknya maka secara otomatis perkembangan pendidikan agama anak akan baik pula. Sebaliknya jika lingkungan keluarga kurang memberikan support kepada anaknya maka perkembangan anak didik akan berbeda jauh dengan hal di atas. Untuk itu, di masa pandemi seperti sekarang ini orang tua peserta didik SDN TOTOSAN I Kec. Batang-batang membimbing dan mengarahkan peserta didik dalam pembelajaran daring agar peserta didik lebih fokus terhadap pelajaran yang ditugaskan oleh guru meskipun terkadang orang tua peserta didik belum bisa memahami pelajaran yang disampaikan guru serta sibuknya orang tua peserta didik dalam mencari nafkah.

\section{Upaya Orang Tua Peserta Didik dalam Mengatasi Problematika Peserta Didik dalam Pembelajaran PAI pada Saat Covid-19 Desa Totosan Dusun Ares Laok Kecamatan Batang-batang}

Dalam situasi pandemi corona yang mengharuskan pemberlakuan lockdown, tentunya semua kegiatan yang diluar rumah harus diberhentikan. Salah satu hal yang menjadi dampak dari kejadian tersebut yaitu kegiatan sekolah. Seharusnya dalam kegiatan sekolah terutama pembelajaran harus dilakukan di lingkungan sekolah, namun karena adanya pemberlakuan lockdown kegiatan yang harus dilakukan di lingkungan sekolah 
harus dilakukan di rumah. Jadi, guru menyampaikan materi pelajaran dengan daring. Dengan pemberlakuan lockdown dan pembelajaran harus dilakukan secara daring, untuk itu orang tua dari peserta didik turun tangan dalam membantu anaknya belajar. Orang tua membaca tugas-tugas dari guru untuk anak jika dimungkinkan, orangtua bisa membantu tugas anak dengan diaplikasikan dalam kehidupan sehari-hari. Seperti yang dilakukan ibu Halimatus sa'diah, ibu Irfan Maulidi salah satu peserta didik kelas III SDN Totosan I Kec Batng-batang, beliau membantu putranya dalam belajar dengan caranya sendiri yang dalam perannya ibu itu mengajarkan pelajaran PAI hafalan surah pendek. Hal tersebut sangat menarik, beliau mengajak putranya untuk mendengarkan langsung dari youtube lalu merekam hafalan tersebut. Dan hasil rekaman itu bisa dikirimkan ke guru kelasnya. Dengan cara tersebut dapat memudahkan anak dalam belajar PAI mengenai cara hafalan surah pendek.

Akan tetapi tidak semua materi yang disampaikan guru bisa langsung dipahami oleh orang tua peserta didik. Pemahaman materi oleh orangtua dalam mendampingi anak belajar di rumah di masa pandemi ini menjadi kendala dalam pelaksanaannya, ditunjukkan dengan hasil wawancara kepada salah satu orang tua peserta didik yang menyatakan bahwa menyampaikan ilmu kepada anak usia dini tidaklah mudah dan membutuhkan latihan khusus. Hal ini sejalan dengan penelitian sebelumnya yang menyatakan bahwa selama pembelajaran di rumah atau daring, banyak orangtua yang kurang dalam memahami materi yang diberikan oleh pihak sekolah atau guru, orang tua menganggap 
tugas yang diberikan terlihat sulit sehingga mereka sulit untuk menyampaikan kepada anak. ${ }^{14}$

Demi tercapainya tujuan untuk membantu mengatasi kesulitan belajar bagi peserta didik, maka sedapat mungkin faktor-faktor yang menjadi penyebab kesulitan belajar harus dihilangkan atau minimal harus dikurangi. Salah satunya yaitu belajar berkelompok dengan salah satu orang tua peserta didik yang dianggap lebih mengerti dan mudah memahami terhadap pelajaran yang diberikan oleh guru karena biasanya anak lebih senang belajar jika bersama dengan teman-temannya. Sedapat mungkin orang memberikan bimbingan dan motivasi, bimbingan dan motivasi dari orang tua ini berupa selalu mengingatkan, menasihati dan memberi semangat anak akan pentingnya belajar yang harus dilakukan oleh anak sekolah. Selain hal itu, peserta didik maupun orang tua peserta didik menginginkan sekolah tatap muka supaya pembelajaran lebih efisien dan efektif.

\section{KESIMPULAN}

Problematika yang sering dihadapi oleh peserta didik dalam menjalani proses pembelajaran daring yaitu pembelajaran kurang maksimal dan kondusif, kurangnya pemahaman materi PAI oleh peserta didik dan orang tua peserta didik, kurangnya ketersediaan handphone dan koneksi jaringan yang buruk serta sibuknya orang tua peserta didik dalam mendampingi peserta didik ketika pembelajaran daring dimulai. Upaya yang dilakukan oleh orang tua peserta didik dalam menangani problematika

\footnotetext{
${ }^{14}$ Rusdiana Retma Jian, Upaya Orang Tua dalam Mengatasi Kesulitan Belajar Anak di Desa Ngantru Kecamatan Ngantru Kabupaten Tulungagung, 2012.
} 
pembelajaran daring dengan cara terus memberi dukungan dan bimbingan sebisa mungkin pada peserta didik serta mengadakan belajar kelompok sesama peserta didik yang dibimbing langsung oleh orang tua peserta didik yang lebih paham.

\section{DAFTAR PUSTAKA}

Arifa, Fieka Nurul. "Tantangan Pelaksanaan Kebijakan Belajar dari Rumah dalam Masa Darurat Covid-19" XII (2020): 14.

Asmuni. "Problematika Pembelajaran Daring di Masa Pandemi Covid-19 dan Solusi Pemecahannya." Penelitian dan pengembangan 7 (2020): 281.

Febriyantika, Rahman Suci. Problematika Pembelajaran Pendidikan Agama Islam (PAI) pada Masa Pandemi Covid-19 di SMP Islam Nurussalam Al-Khoir Mojolaban Sukoharjo Tahun Pelajaran 2019/2020, n.d.

Guswanti, Mulia, and Rengga Satria. "Problematika Pembelajaran dalam Problematika Pembelajaran dalam Jaringan (Daring) pada Mata Pelajaran Pendidikan Agama Islam di SMA Negeri 4 Pariaman." An-Nuha 1, no. 2 (2021): 116-124.

J Moleng, Lexi. Metodologi Penelitian Kualitatif. Bandung: Remaja Rosda Karya, 2009.

Jian, Rusdiana Retma. Upaya Orang Tua dalam Mengatasi Kesulitan Belajar Anak di Desa Ngantru Kecamatan Ngantru Kabupaten Tulungagung, 2012.

Nugroho, M. Yusuf Amin. "Metode, Media, dan Problematika Pembelajaran PAI Berbasis Daring di Tingkat Madrasah Aliyah." Paramurobi: Jurnal Pendidikan Agama Islam 3, no. 2 (2020): 1-14.

Rahman, Suci Febrientika. "Problematika Pembelajaran Agama Islam pada Masa Pandemi Covid-19 di SMP Islam Nurus Salam" 3 (2020).

Rusli, Muhammad. Pedoman Praktis Membuat Proposal dan Laporan Penelitian Lapangan. Sumenep: LP3M Paramadani, 2013.

Susiana. "Problematika Pembelajaran PAI di SMKN 1 Turen." At Tariqah 2 (2017): 73. 
Fitriyan, Firda Ayu Wahyuni | MAHAROT Vol. 5 No. 1, 2021

Yuliana. "Corona Virus Diseases (Covid-19): Sebuah Tinjauan Literatur" 2 (2020). 